\title{
Family members as hybrid owner-managers in family-owned newspaper companies: handling multiple institutional logics
}

\author{
Börje Boers \\ School of Business, University of Skövde, Skövde, Sweden, and \\ Thomas Andersson \\ School of Business, University of Skövde, Skövde, Sweden and \\ Faculty of Theology, Diaconia and Leadership Studies, VID Specialized University, \\ Oslo, Norway
}

\begin{abstract}
Purpose-This article aims to increase the understanding of the role of individual actors and arenas in dealing with multiple institutional logics in family firms.

Design/methodology/approach - This study follows a case-study approach of two family-owned newspaper companies. Based on interviews and secondary sources, the empirical material was analysed focussing on three institutional logics, that is, family logic, management logic and journalistic logic.

Findings - First, the authors show how and in which arenas competing logics are balanced in family-owned newspaper companies. Second, the authors highlight that family owners are central actors in the process of balancing different institutional logics. Further, they analyse how family members can become hybrid ownermanagers, meaning that they have access to all institutional logics and become central actors in the balancing process.

Originality/value - The authors reveal how multiple institutional logics are balanced in family firms by including formal actors and arenas as additional lenses. Therefore, owning family members, especially hybrid owner-managers, are the best-suited individual actors to balance competing logics. Hybrid owner-managers are members of the owner families who are also skilled in one or several professions.
\end{abstract}

Keywords Institutional logics, Family firms, Hybrid owner-managers, Formal arenas, Journalistic logic

Paper type Research paper

\section{Introduction}

Family businesses have been described and analysed as hybrid organisations that combine the normative element of a family and the utilitarian element of a business (Arregle et al., 2007; Boers and Nordqvist, 2012, 2020; Foreman and Whetten, 2002). Hybrid organisations place special demands on organisational members to handle tensions that arise from this hybrid character (Albert and Adams, 2002; Albert et al., 1999; Blomgren and Waks, 2015; Foreman and Whetten, 2002; Jager and Schroer, 2014). Recently, researchers have argued that the hybrid character is based on multiple institutional logics (Pache and Santos, 2013; Perkmann et al., 2019).

Research has been indecisive regarding the consequences of multiple logics (Besharov and Smith, 2014). However, institutional logics research has started to direct more attention

(C) Börje Boers and Thomas Andersson. Published by Emerald Publishing Limited. This article is published under the Creative Commons Attribution (CC BY 4.0) licence. Anyone may reproduce, distribute, translate and create derivative works of this article (for both commercial and non-commercial purposes), subject to full attribution to the original publication and authors. The full terms of this licence may be seen at http://creativecommons.org/licences/by/4.0/legalcode

Received 30 June 2021 Revised 1 October 2021 30 November 2021 Accepted 30 November 2021 members as hybrid ownermanagers 
towards how individual actors make sense of and deal with multiple institutional logics (e.g. Andersson and Gadolin, 2020; Andersson and Liff, 2018; Bévort and Suddaby, 2016; McPherson and Sauder, 2013; Reay et al., 2017), which make institutional logics more "inhabited" (Everitt, 2012) and ascribe more agency to individual actors (Alvehus and Andersson, 2018). It is only recently that the institutional logics perspective (Thornton et al., 2012) has entered family business research (e.g. Basco, 2019; Miller et al., 2011; Reay, 2009; Reay et al., 2015). This perspective has started to build knowledge about the relationship between family firms and their institutional context (Soleimanof et al., 2018). For example, Reay et al. (2015) directed attention to the importance of understanding family business beyond just business and family logic, as there can be additional logics that further increase complexity, such as community logics (Reay et al., 2015), bureaucratic logics (Thornton et al., 2012) and professional logics (Goodrick and Reay, 2011). However, although the institutional logics perspective has made important contributions to family business research, the abovementioned turn towards individuals dealing with institutional logics is not yet salient in family business research.

From contexts other than family firms, hybrid managers (Currie et al., 2015) and hybrid professionals (Blomgren and Waks, 2015) have proven important in terms of dealing with multiple institutional logics. In other contexts, however, hybrid mainly refers to managerial logic and different professional/occupational logics, whereas family logic is an important aspect of hybridity in family firms (e.g. Arregle et al., 2007; Boers and Nordqvist, 2012).

The present article aims to connect this newer strand of institutional logics research, emphasising individual actors with family business research, in order to contribute to how individuals in family firms deal with multiple institutional logics. The purpose of the paper is to increase the understanding of the role of individual actors in dealing with multiple institutional logics in family firms.

The paper is based on an in-depth case study of two family firms in the newspaper industry. This industry combines several institutional logics, such as journalistic and management logic (Achtenhagen and Raviola, 2009), as well as family logic in the two studied cases. In this paper, we intend to make the following contributions. First, we show how competing logics are dealt with in family-owned newspaper companies. Second, we highlight that family owners are central actors in the process of balancing different institutional logics. Further, we analyse how family members can become hybrid owner-managers, meaning that they have access to all institutional logics and become central actors in the balancing process. We begin with an overview of the literature and define our key concepts, before outlining the method and offering empirical illustrations and analysis. Finally, we offer a discussion and then some conclusions.

\section{Theoretical framework}

In this framework, we present and discuss the central concepts of our paper. Multiple institutional logics are used to understand the institutional setting of family business, and we aim to understand how individual actors within the business deal with these multiple institutional logics. Institutional logics are often used to understand individual behaviour (Thornton et al., 2012); however, under conditions of institutional complexity (i.e. multiple institutional logics), individual actors exercise a remarkable degree of autonomy in their day-to-day practice (Hallett, 2010). It seems that their actions are not strongly determined by institutional logics. This is explained by the fact that different institutional logics provide diverging (but possibly also competing) prescriptions of individual behaviour and thereby also more autonomy (Martin et al., 2017). It is this process of individuals dealing with multiple institutional logics in family business that the theoretical framework is designed to capture. 


\subsection{Multiple institutional logics in family business}

In this study, we define a family business as a company that has lasted over generations, with significant involvement of a single family, or several families, as owner(s) and manager(s) (Astrachan et al., 2002; Chua et al., 1999). In other words, owning families control the business and have considerations towards it other than just financial wealth (see Boers et al., 2017; Gómez-Mejia et al., 2011; Nordqvist, 2016). Specifically, the owning family members influence the business through decision-making and become central actors (Brundin et al., 2014).

Family business is not only a matter of business logic; it combines the two institutions of the family and the business into a single organisation (Boers and Nordqvist, 2012; Leaptrott, 2005; Melin and Nordqvist, 2007; Nordqvist and Melin, 2002; Parada et al., 2010, 2020; Zaman et al., 2021). Nevertheless, scholars disagree as to whether or not family and business logics are competing or complementary (Reay et al., 2015).

The institutions of family and business can be connected to specific institutional logics, such as family, market and bureaucratic logics (see Reay et al., 2015). Because the family businesses in this study are newspapers, the journalistic logic is also present. These logics encompass different characteristics that create complexity within the family business. We argue that in order to understand family business, we need to understand the coexistence of different competing logics and the complexity these competing logics create. Balancing the different expectations and requirements that emanate from different logics may be a key competence for family businesses (Reay, 2009), and the institutional logics framework is useful for understanding this situation (Thornton et al., 2012).

Thornton and Ocasio (2008, p. 101) defined an institutional logic as "the socially constructed, historical patterns of material practices, assumptions, values, beliefs, and rules by which individuals produce and reproduce their material subsistence, organize time and space, and provide meaning to their social reality." Institutional logics guide social actions (Greenwood et al., 2010) by providing assumptions and values on how to interpret organisational reality (Thornton, 2004). The many different (and often competing) institutional logics that are at play simultaneously in family business create institutional complexity (Jaskiewicz et al., 2016; Miller et al., 2011), as different institutional logics provide different interpretations of reality. Table 1 presents the ideal types of management, family and journalistic logics essential for this study.

The two first logics in particular have often been described and analysed in previous family business research (e.g. Aparicio et al., 2017; Basco, 2019; Jaskiewicz et al., 2016; Reay et al., 2015). Less focus has been directed towards the different professional/occupational logics that may also exist in a firm, such as journalistic logic in our case of newspaper companies (e.g. Achtenhagen and Raviola, 2009). The more logics that are in play, the higher the institutional complexity will be (Greenwood et al., 2011), as long as none of them is dominant (Andersson and Gadolin, 2020).

Journalistic logic encompasses the meeting point between two ideal types of logic: professional and artistic. Professional logic is based on professional expertise grounded in scientific knowledge and capabilities that generates different degrees of autonomy (Freidson, 2001). For journalists, artistic knowledge and capabilities (Achtenhagen and Raviola, 2009) may be just as strong, or even stronger, than reliance on science. Professions generally strive for autonomy to act and make decisions according to professional knowledge and ethics, rather than organisational belonging (Gadolin and Andersson, 2017). To uphold this jurisdiction to a knowledge domain (Abbott, 1988), and the right of autonomy, professionals must prove that they are acting according to a service ideal (Liff and Andersson, 2011). In the case of journalists, this means acting towards members of society who rely on them to represent public interest (Hallin and Mancini, 2004). Conflicts between journalistic logic and more commercial logics (management logic) are typically handled by a dual organisational structure with an editor-in-chief, who is formally in
Family members as hybrid ownermanagers

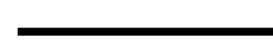




\section{JFBM}

\begin{tabular}{|c|c|c|}
\hline Logic & Key values & Firm behaviour in ideal type \\
\hline $\begin{array}{l}\text { Family (adapted from } \\
\text { Reay et al., 2015) }\end{array}$ & $\begin{array}{l}\text { - Unconditional loyalty to family } \\
\text { underlies business practices } \\
\text { - Firm identity relies on family } \\
\text { reputation } \\
\text { - Family membership determines } \\
\text { status within firm }\end{array}$ & $\begin{array}{l}\text { - Firm is organized to benefit family } \\
\text { members } \\
\text { - Family members make all key } \\
\text { decisions } \\
\text { - Family tradition guides decision- } \\
\text { making }\end{array}$ \\
\hline $\begin{array}{l}\text { Management (market and } \\
\text { bureaucracy) (derived } \\
\text { from Thornton et al., 2012; } \\
\text { Jaskiewicz et al., 2016; } \\
\text { Reay et al., 2015; } \\
\text { Andersson and Liff, 2018) }\end{array}$ & $\begin{array}{l}\text { - Achieving maximum value from } \\
\text { transactions determines business } \\
\text { value } \\
\text { - Success in the market and } \\
\text { professional management } \\
\text { establishes firm reputation } \\
\text { - Efficiency underlies profitability }\end{array}$ & $\begin{array}{l}\text { - Firm is hierarchical, based on } \\
\text { positions to focus on profitability } \\
\text { - Firm competes to increase sales } \\
\text { - Firm processes are developed by } \\
\text { managers to maximize efficiency }\end{array}$ \\
\hline $\begin{array}{l}\text { Journalistic (artistic and } \\
\text { professional) (derived } \\
\text { from Achtenhagen and } \\
\text { Raviola, 2009; Andersson } \\
\text { and Liff, 2018) }\end{array}$ & $\begin{array}{l}\text { - Artistic and professional values } \\
\text { underlie business practice } \\
\text { - Artistic and professional } \\
\text { competence and autonomy is } \\
\text { central }\end{array}$ & $\begin{array}{l}\text { - Firm is organized to guarantee } \\
\text { artistic and professional freedom } \\
\text { - Decisions are based on artistic and } \\
\text { professional values } \\
\text { - Firm competes based on artistic and } \\
\text { professional contribution }\end{array}$ \\
\hline
\end{tabular}

Table 1

Ideal types of family, management and journalistic logics charge of the artistic/journalistic product, and a publisher, who is the product manager for the commercial side.

Family business research often uses professional management as a concept (Hall and Nordqvist, 2008; Songini, 2006; Songini and Vola, 2014, 2015) when referring to what we call management logic. Professional management then means the formalisation and professionalisation of the management function, organisation and managers (Hall and Nordqvist, 2008), but it can also refer to the relationship between management and family (Polat, 2021). Previous family business research, applying an institutional-logics perspective, mainly focussed on marketing and commercialisation logic, which often conflicted with family logic (e.g. Basco, 2019; Jaskiewicz et al., 2016; Reay et al., 2015). While market logic is important, management logic also contains bureaucratic logic (Andersson and Liff, 2018) because managers and formalisation become the visible hand that dealt with the market (Chandler, 1990). Therefore, the bureaucratisation of family business creates arenas (such as board meetings) and actors (such as managers) to deal with different institutional logics and competing interpretations of reality (cf. Polat, 2021).

Family logic differs from market logic in several ways. Whereas family logic emphasises concepts such as distance to capital markets, a long-term orientation or multiple goals (Brundin et al., 2014), market logic emphasises shareholder value and a short-term orientation (Thornton et al., 2012). Family logic entails multiple goals, but the shareholder-value approach sees the primary goal as maximising value for shareholders; in other words, profit maximisation. Owning families usually have goals other than profit maximisation, which is not necessarily primary. For example, long-term orientation, longevity and organisational survival may be more important goals (Sharma et al., 2014). We argue that managers, especially owner-managers with "full access" to different worlds, play important roles in balancing these different logics. Formalisation provides different arenas in which to do that, but there might also be arenas that only family members can access (Matias and Franco, 2021).

\subsection{Individual actors dealing with institutional logics in family business}

A family business contains multiple institutional logics that are sometimes competing and sometimes complementary (Jaskiewicz et al., 2016). An under-studied area in institutional- 
logics research regards individual actors and arenas that are important for dealing with these logics (Nordqvist, 2012). In general, researchers claim that the individual actor level has been under-studied in institutional-logics research (Andersson and Liff, 2018; Bévort and Suddaby, 2016; McPherson and Sauder, 2013; Reay et al., 2017).

Several researchers (e.g. James et al., 2021) have argued that there is a need to focus more on cultural competence, which can be defined as "an understanding of the unique sociocultural patterns originating from the family's influence on a business" (Hall and Nordqvist, 2008, p. 62). This understanding is difficult to achieve and is sometimes only accessible for family members. Furthermore, it implies that there are different strategic arenas, based on family and firm contexts on the one hand and informal (culturally based) and formal (structurally based) on the other hand (Matias and Franco, 2021; Nordqvist, 2012). These different arenas are not necessarily accessible for all actors. Hybrid arenas containing both formal and informal elements are especially important in the process of balancing institutional logics. These hybrid arenas contain both formal and informal elements. Such a hybrid mix of formality and informality adds to complexity (Nordqvist, 2012) but enables family businesses' strategic work to combine both family and managerial logics (see Brundin and Melin, 2012; Miller et al., 2011). Based on the understanding that family businesses need formal (management) and cultural competences, Stewart and Hitt (2012) emphasised that family business owners can balance the tensions that result from acting managerially and being a family business.

Family business research has already noted that family members often occupy multiple roles to deal with multiple demands (Gersick et al., 1997; Tagiuri and Davis, 1996) because of their particular suitability for addressing and mediating the different demands from family and business, which might sometimes appear paradoxical (Ingram et al., 2016). Family members might constitute hybrid owner-managers who are central in responding to demands resulting from different logics, ensuring the continuity of the family firm (see Jaskiewicz et al., 2016; Konopaski et al., 2015; Salvato et al., 2010; Steinerowska-Streb and Wziatek-Stasko, 2020). While "Hybrid then refers to managers who are skilled in an alternative profession" (Currie et al., 2015), the term has not been used in the family business context. In healthcare, it means a person with a medical education background who takes on a management position (Andersson, 2015; Currie and Spyridonidis, 2016), which can result in high demands and need to separate roles with the help of different mechanisms (Reay and Hinings, 2009). However, research in other contexts has shown how individual actors working in conditions with multiple institutional logics often adhere mainly to one institutional logic, called their "home" logic (McPherson and Sauder, 2013). By adhering mainly to one logic, they reduce the institutional complexity (Andersson and Gadolin, 2020), but do not really deal with the multiple institutional logics. As a result, while hybrids may not be taken for granted, they require a lot of the individual actors to take on such a role.

An often-mentioned mechanism in family business is the separation between the family and the management roles (Bjursell and Bäckvall, 2011). This is often combined with a demand to include non-family members in professional roles (Dyer, 1989). However, this mechanism runs the risk of missing important knowledge regarding the owning families' goals and vision or the cultural competence (Hall and Nordqvist, 2008).

In family firms, arenas can be formal or informal (Nordqvist, 2012). In principle, these arenas are available to both family and non-family members. Accessing informal arenas of family firms requires trust and competence, which is more difficult for non-family members to obtain (Hall and Nordqvist, 2008).

Nordqvist (2012) argued that there are several hybrid arenas in family firms (see Table 2). These arenas can combine formal and informal, as well as family and firm contexts, and thereby increase complexity. The present study focusses on formal arenas, as we argue that 
different logics are more salient there. Nevertheless, due to the nature of family firms, even the formal arenas contain informal elements (Matias and Franco, 2021; Nordqvist, 2012).

\section{Method}

\subsection{Case selection}

This study is based on two family-owned newspaper companies, and purposive sampling was applied (Eisenhardt, 1989; Eisenhardt and Graebner, 2007). The study follows an indepth, case-study approach (Nordqvist et al., 2009). A qualitative approach is both suitable and common for studying institutional logics, as it allows us to capture the socially constructed nature of the logics (Reay and Jones, 2016) and has been called for (Aparicio et al., 2017). This approach also allows us to acknowledge the particularities of the studied context (Gadolin, 2018).

Family ownership and involvement were the necessary conditions for company selection, along with having at least one succession, in order to account for family dynamics (Chua et al., 1999). Furthermore, the newspaper industry was chosen because it is known for its family ownership (Djankov et al., 2003; Picard, 2004). Additionally, the size of the selected companies was similar in terms of turnover. Access to the studied companies was another essential reason for selection (Nordqvist et al., 2009; Siggelkow, 2007).

\subsection{Collecting data}

We used several different sources for data collection, which is recommended as it increases trustworthiness (De Massis and Kotlar, 2014).

Interviews are useful for understanding complex issues, not least in family firms (Reay and Jones, 2015). The recorded and transcribed interviews lasted between 60 and $180 \mathrm{~min}$. As part of the procedure, an interview guide was used that covered aspects such as the company, owning family, board of directors and the relationship between the newspaper and its owners; in other words, issues of governance and family involvement in management and editorial work.

A total of 16 interviews were conducted with 14 people at City News [1], meaning that two respondents were interviewed twice. As the business is already in its fourth generation of ownership, the interviews were complemented by a literature study using autobiographies and portraits about the first and second generations and information from other media sources. Thirty-six interviews were conducted at River News [2]. Following Leonard-Barton's (1990) methodology for reporting longitudinal case studies, Table 3 shows our timeline of data collection and use of data sources.

\subsection{Background to the studied companies}

River News is active in Germany, the Czech Republic, Poland and the Netherlands. In 2011, the organisation's turnover was approximately $€ 500 \mathrm{~m}$, and it had 4,700 employees. It is owned by four families and Company $\mathrm{C}$, a competing publishing house with interlocking

Table 2. Arenas and institutional logics

\begin{tabular}{lll}
\hline Logics & Formal arenas & Informal arenas \\
\hline Family & Shareholders' meetings, family councils, other & $\begin{array}{l}\text { Ad-hoc meetings at home, family meetings, } \\
\text { casual conversations }\end{array}$ \\
Management & Manal family meetings & Ad-hoc meetings, casual conversations \\
Journalistic & Editorial conference, publishers conference & Ad-hoc meetings, casual conversations \\
Source(s): Inspired by Nordqvist (2012) & \\
\hline
\end{tabular}


shareholdings. Three of the families are founding families and now in the third generation of owning the firm, and one family owns the company in the second generation. Moreover, River News and Company $\mathrm{C}$ compete and collaborate in several markets.

River News is organised into nine business segments, divided into domestic (German) and international. The holding company has three managing directors, who have responsibility for the business segments. Until recently, only non-family managers held executive positions. However, the son of the chairman of the supervisory board (family G1) became managing director and is the designated chairman of the management board. The four owning families are the publishers of River News.

City News portrays itself as a growing media group and one of the biggest newspaper owners in Sweden. In 2009, the group had annual turnover exceeding $€ 500 \mathrm{~m}$. The firm is controlled by an owning family in the third generation.

City News has six business areas, which correspond to different businesses, including the founding newspaper East-News, the printing section, local newspapers in central Sweden, newspapers on the Swedish East coast and free weekly advertising newspapers in and around Stockholm. The last business area contains different acquired units in the field of new media.

\subsection{Analysing information}

It is reasonable that researchers reveal how they analysed their findings and reached their conclusions in order to ensure rigor and trustworthiness (De Massis and Kotlar, 2014; Eisenhardt and Graebner, 2007; Fletcher et al., 2016). This also helps trace the process of capturing the different logics (Reay and Jones, 2015).

The interviews were transcribed and the texts were analysed by searching for patterns and themes relating to the three ideal typical logics (Reay and Jones, 2016). Section 3.5 provides context to the study, Section 4 shows empirical illustrations, based on three formal arenas (cf. Nordqvist, 2012), and Section 5 discusses the empirical findings. We displayed the themes in the form of tables (Tables 4-6), which contain illustrative quotes from the material, in addition to the respondents, interpretation of the quotes and their implication for balancing the different logics. The tables represent the three identified arenas in which the different logics meet (Nordqvist, 2012).

We analysed the information with management, family and journalistic logics in mind. The empirical material was grouped into themes that were deemed relevant for understanding how individual actors dealt with the different logics. The owning families were the focal actors.

To understand how these logics were handled, we identified arenas (Nordqvist, 2012) in which the logics typically interacted. These arenas were the board of directors, the management board and the editorial and publishers' conference.

\begin{tabular}{llr}
\hline Data sources & Company & Number \\
\hline Authors' interviews & City News (2008-2014) & 16 \\
& River News (2009-2013) & 36 \\
Archival data: including annual reports, business magazine & City News (2008-2014) & 15 \\
interviews, and general press clips & River News (2009-2013) & 29 \\
Autobiographies covering owners' personal viewpoints & City News & 2 \\
& River News & 1 \\
Field-level data from German and Swedish family firms & Germany (2009-2013) & 5 \\
& Sweden (2008-2014) & 9
\end{tabular}

Table 3.

Data sources 
JFBM

Table 4.

Arena 1: Board of directors

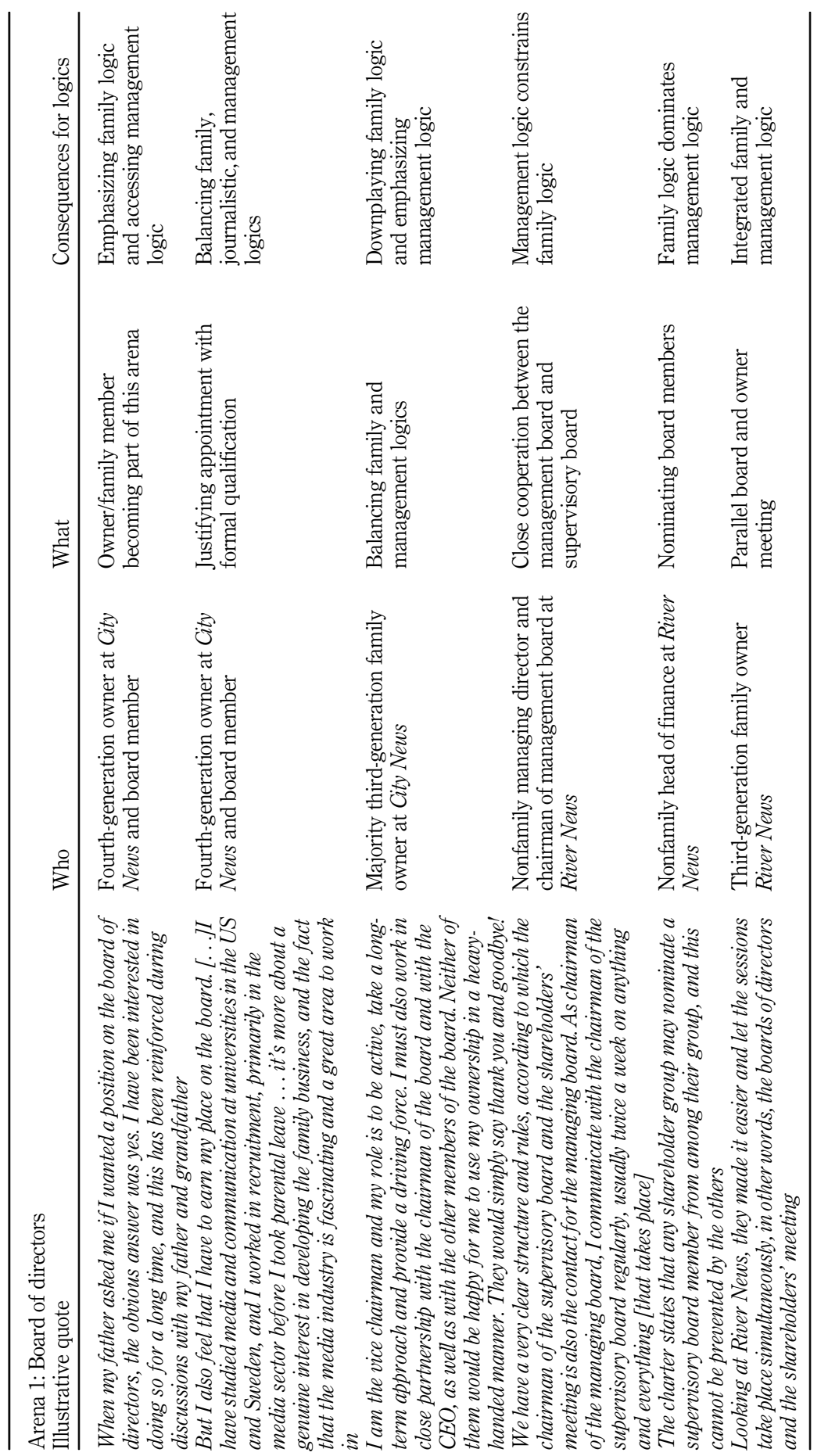


Arena 2: Management board Illustrative quote

Dr. Meier, who is the son of our chairman, was appointed managing director, because, well, he brings good qualifications and because it was a necessary decision due to retirement and the like in the previous management.

Succession had to be regulated, and Dr Meier was mentioned, which from our viewpoint I actually think was a good decision, because he worked for many years in international publishing houses and he also has media experience

Dr. Meier actually behaves exactly as you would expect from any other external manager

There has to be a certain qualification. This is required in our charter. You can imagine that we would have hard times if we appointed a naval engineer as technical director, someone who has no idea of printing and printing presses

[...] in the early 1990s when the third generation was $C E O$, before becoming editor in chief of the newspaper. In the beginning when he arrived as editor in chief there were many who mixed up roles. I think it was inconvenient for him. It was difficult for many around him

Who What Consequences for logics

Nonfamily head Justifying appointment of finance at with experience and River News formal qualification

Nonfamily head of finance at River News

Nonfamily CFO at River News

Vice-Editor-in- Role conflicts Chief at City News
Downplaying family logic: Legitimated by management logic and journalistic logic
Emphasizing accordance with managerial owner role to others

Referring to formal rules that are valid for all expectations and avoiding
Downplaying family logic by emphasizing managerial code of conduct, or management logic Using management logic to support journalistic logic
Family members as hybrid ownermanagers
Table 5.

Arena 2: Management board

\subsection{Context: family-owned newspaper companies}

The media industry, particularly newspapers (Djankov et al., 2003; Picard and van Weezel, 2008; Sundin, 2009), is an example of where family ownership dominates (Andersson et al., 2018). Newspaper organisations are characterised by the duality of an artistic and a business mission (Achtenhagen and Raviola, 2009; Raviola, 2012). Consequently, many newspaper organisations have a dual organisational structure, with one editor-in-chief managing the journalistic product and a CEO managing the business (Achtenhagen and Raviola, 2009; Djerf-Pierre and Weibull, 2011; Raviola, 2012). Some have argued that this is part of newspapers' development towards a more management-influenced endeavour (Djerf-Pierre and Weibull, 2011), and a step toward a business orientation, particularly if family-owned (Dyer, 1989). 
Arena 3: Editorial Board Illustrative quote
The newspapers in Germany have a
public function by law. I am very aware of it. A newspaper company or a radio broadcaster is something special. It is a public duty. If you open a shoe factory, you do not have a public duty. This results in special obligations for the press Newspapers have an important role, not least from a societal perspective, and therefore we have that motive also in our interest that we contribute to the continued development of good society Our managers are not just "flown in" people who have worked at a soap factory, and the next day at a car supplier, but they are people who come from the media, who have already spent a relatively long time here, they fit in with us

The power is clear. You know who takes the final decision. Decision lines are shorter. And it is not just profitability that is our driving force, but there are journalistic goals

I believe that just such products ... Media-culture products ... which are also sold in a journalistic quality, are more important in an industry. Perhaps they can even be done rational at one point or another. Who judges editorial quality?

I am chairman of the publisher's conference. This is a meeting with the publishers and the senior editors which takes place at irregular intervals. There, we discuss all the topics that I choose in advance, which are of interest for the newspaper, and have an open debate about them. There are no protocols for the results. It always ends so that we reach a fundamental agreement on the questions between publishers and senior editors

I know that I must be careful that the figures are in order. As long as this is the case, I can determine relatively freely, so to speak, about journalism If you have good relations with your owners, publishers, directors and explain why you take your position, then this is also accepted
Table 6.

Arena 3:

Editorial board

Consequences for logics

Emphasizing journalistic logic

Second-generation Owner/family owner, chairman of member justifies the board and the the journalistic editorial conference mission at River News

\section{Nonfamily CEO,} City News

Underlining the journalistic mission

Emphasizing journalistic logic

Editor-in-chief at River News

Relevance of media affinity

Third-generation owner/manager at City News

Third-generation owner/manager at River News

Second-generation owner/chairman of the board and the editorial conference at River News

Editor-in-chief at River News

Editor in chief at River News
Owner families control and moderate the discussions
Owners decide management and journalistic goals

Owner families protect the journalistic quality
Journalistic logic as part of the organizational culture

Owner families combine journalistic logic and management logic

Owner families as guardians of journalistic logic
Family logic mediates management logic and journalistic logic
Balancing business and journalism

Anchoring journalistic decisions with management and family logics
Management logic supports journalistic logic

Securing journalistic logic by relating to management logic and family logic 
Arena 3: Editorial Board

Illustrative quote
We feel part of this family, and accept
their values and their rules and are
happy to join in, so to speak, because
that's our common family. This is now
independent of whether they [the
publishers] are with us in the imprint or
not

Responsible yes, it is clear, since a large majority of Swedes still get some of their information from the morning paper, the group, we all have a great responsibility

Newspapers have an important role, not least from a societal perspective, and therefore we have that motive also in our interest that we contribute to the continued development of good society The digital age creates a transparency in almost all relationships. It fits the City News who always defends the open and free society in which, not in the least, the newspaper has an important journalistic task

We do discuss editorial issues, questions, and structures pretty often. Because, especially in the phase where we are right now, it's a challenge. We actually discuss what their role is, because the role is changing
Consequences for logics

Family logic determines journalistic logic

Family members as hybrid ownermanagers

Editor-in-chief at online edition, River News

Journalism adapt family values

Third-generation owner, City News

\section{Nonfamily CEO, City News}

Third-generation owner, City News

Nonfamily CEO, Changing roles City News
Being responsible owners

Manager
emphasizes the
public interest

Family mission is a societal mission
Emphasizing journalistic logic

Emphasizing journalistic logic

Emphasizing journalistic logic

Management and journalistic logics interact

Media businesses, particularly newspapers, are facing a dilemma. On the one hand, they play a central role in democratic societies by freely expressing opinions and serving the public interest, which is legally codified in some countries (Hallin and Mancini, 2004). On the other hand, newspapers are mostly commercial enterprises that serve the (commercial) interests of their owners. For example, Dybski et al. (2010) found that the economic self-interest of publishers can affect reporting issues, potentially conflicting with the subscribed public task connected to journalistic logic.

\section{Results, analysis and discussion}

We present empirical illustrations of three formal arenas (Nordqvist, 2012) in which multiple logics are created. As described in Section 3, the formal arenas are the places where multiple institutional logics are most likely to conflict. The notion of informal arenas can be seen in supporting the respective logics. Moreover, we illustrate how family owners and other actors become hybrid managers.

\subsection{Arena 1: board of directors}

This formal arena clearly shows how family actors must legitimise their access to this arena. It seems that the owners balance or even downplay the family logic in favour of the 
management logic in their comments. However, family logic is also appealing from an outsider perspective. With regard to ownership, we found that family logic was balanced and reconciled with management logic in both companies. This is in line with prior studies (cf. Boers and Nordqvist, 2012; Brundin et al., 2014; Jaskiewicz et al., 2016; Zellweger et al., 2013). However, even journalistic logic plays a role at the ownership level, highlighting the multiple roles of owning family members. Both organisations emphasise management logic with regard to being an owner. Nevertheless, family logic can take over or pave the way for management logic. In other words, it is not unidirectional; instead, context and circumstances decide which logic takes over (Soleimanof et al., 2018; Wright et al., 2014).

We also found representative quotes of balancing family and management logic in both firms. In part, the board represents the formal arena (management logic), which represents owner interests (family logic) (cf. Nordqvist, 2012). However, the relationship is neither fixed nor predetermined. Rather, the relationship changes and requires active balancing of work for owning family members, illustrating its hybrid character (Nordqvist, 2012).

\subsection{Arena 2: management board}

The management board is a formal arena with high, formal entry requirements. River News emphasises management logic to downplay family logic, which is explicitly expressed in City News. The underlying reasons are presumably due to the different types of appointment. River News appoints a managing director, while City News appoints a board member. Nevertheless, the family logic is clearly present in both companies, which means that balance is required.

\subsection{Arena 3: editorial board}

In journalistic arenas, journalistic logic is balanced with both management and family logics. Again, the multiple roles of owning family members necessitate a balance between potentially conflicting logics (Achtenhagen and Raviola, 2009; Raviola and Norbäck, 2013). However, the nature of this conflict is different in family firms due to the added family logic.

\subsection{Individual actors balancing three different logics}

Family-owned newspaper businesses represent a complex example, with their own specific overlapping institutional logics. Considering the industrial context, we have shown that family logic meets two further logics: management logic (Andersson and Liff, 2018) and journalistic logic (Achtenhagen and Raviola, 2009; Raviola, 2012). Previous research (e.g. Jaskiewicz et al., 2016; Reay et al., 2015) has estimably described the tension between market/ commercialisation logic and family logic. Our focus on management logic means that, in addition to market/commercialisation logic, we also consider bureaucratic logic, as management logic consists of both (Andersson and Liff, 2018). The bureaucratic logic was an important addition because it created formal arenas (cf. Nordqvist, 2012) that were important for individual actors when dealing with different institutional logics. Other research (Parada et al., 2020) has suggested that such structures may only be a matter of ceremonial adoption that do not really provide functionality, although in our cases they served important roles in balancing different logics. While it can be challenging to handle tensions arising from the interaction of these three logics, this is a typical task for family businesses. Owning family members who are active in their organisation are the most important link between the family and the business (Basco, 2019). Individual actors, such as family or non-family members, must handle the resulting tensions of competing logics. Previous research from other fields has emphasised that hybrid managers (Currie et al., 2015) and hybrid professionals (Blomgren and Waks, 2015) are important in terms of dealing with 
conflicting management and professional logics (which resembles journalistic logic in our study). Still, this is not sufficient in the family business context, as it particularly requires cultural competence (Hall and Nordqvist, 2008), in which family logic is an essential part. Therefore, these hybrid managers must adapt to these particular requirements, which are much more difficult for non-family members than for family members, particularly when family members act as gatekeepers for different logics and arenas (cf. Nordqvist, 2012). Instead, we propose that it is more natural for the individual actor who balances these multiple logics to be a member of the owning family; a hybrid owner-manager who possesses the necessary formal qualifications and, by belonging to the owning family, can access the formal and informal arenas (cf. Table 2; Figure 1) that are usually restricted to family members (Hall and Nordqvist, 2008; Nordqvist, 2012). An owner-manager embodies both family and management logics (see 1 in Figure 1). If the owner-manager can balance the two logics, they could be considered a hybrid. However, considering the third logic, a hybrid owner-manager should understand, interpret and act in accordance with all three logics and deal with their inherent conflicts (confer 4 in Figure 1). In our case, hybrid owner-managers are essential for dealing with such conflicts and using different strategies, depending on the formal arena (cf. Nordqvist, 2012) and situation. Sometimes they downplay one logic, emphasise another or use one logic to justify another. Hybrid managers who are not ownermanagers (see 3 in Figure 1) may lack an important dimension to which they have little or no access - family logic (Hall and Nordqvist, 2008; Nordqvist, 2012). Therefore, hybrid ownermanagers have better conditions for balancing logics in family businesses.

This study describes how the relationships and balance between logics are neither stable nor constant, but are context-dependent (Reay and Hinings, 2009; Reay and Jones, 2015). This sheds light on the individual actors who deal with them (Currie et al. 2015; Bevort and Suddaby, 2016). However, the study also describes how the firm can create better conditions for dealing with competing logics by creating and providing formal arenas (Nordqvist, 2012) that can balance different institutional logics. Unsurprisingly, owning family members are the most active in this task. Being a member of an owning family does not mean that family logic is always prioritised. Earlier findings show how family logic dominates another logic (Jaskiewicz et al., 2016), but the present study emphasises that even if family logic could dominate, family owners actively work to balance it with other logics, often by downplaying family logics in favour of other logics. Family members even ensure that other logics are strengthened to avoid destructive dominance of family logic.

Through individual actors (mainly hybrid owner-managers) acting on formal arenas, interpretation of family logic becomes context-sensitive, as it interacts with competing logics in different ways. The interaction can be based on active balancing by family owners, such as

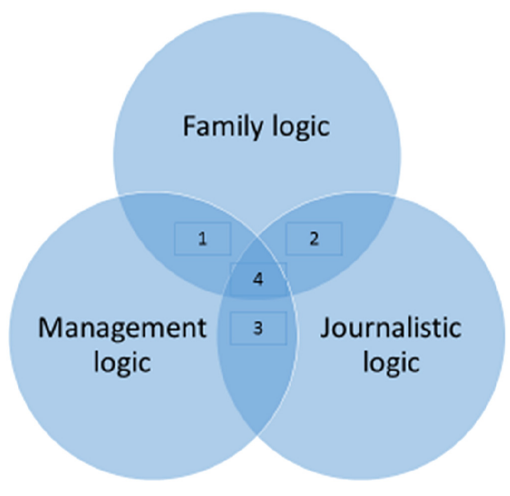

Figure 1. Institutional logics' overlap and actors

members as hybrid ownermanagers

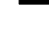


taking management structure and competence seriously, or by creating structures that ensure journalistic influence. However, the interaction can also be more subtle and more informal, as when family owners reconcile logics in situations in which conflicts of interests could appear. Nevertheless, it is mainly the owning family members who balance logics and decide which one dominates. This brings the logics into closeness, proximity to the individual actors (Bevort and Suddaby, 2016). Empirically, we categorised different types of formal arenas with different underlying logics (Reay and Jones, 2016) that are balanced with other logics in different ways (Tables 4-6; Figure 1). Figure 1 illustrates the overlap of the three logics. There are four possible overlaps that require hybrid managers.

Overall, we show that there are more than two logics at work. These logics influence decision-making and the general discourse in family businesses, and owning families moderate the logics by balancing or reconciling them.

\section{Conclusions}

In line with recent calls for additional research (Jaskiewicz et al., 2016; Reay et al., 2015; Soleimanof et al., 2018; Wright et al., 2014), we argue that a more fine-grained perspective on multiple institutional logics in family firms is adequate. We describe how individual actors deal with multiple institutional logics in family firms. The purpose of the present paper is to increase the understanding of the role of individual actors in balancing competing logics in family firms. The paper reveals the following contributions.

In family firms with strong occupations/professions, such as the newspaper industry, where journalists have strong positions, professional logic (journalistic logic) must be considered. Family business research has not paid much attention to this institutional logic when studying family firms. Identifying this institutional logic is important in order to understand the competing institutional logics in family business.

Another contribution relates to identifying owning family members - especially hybrid owner-managers - as the individual actors who are best suited to balance competing logics. It is often these individual actors who carry and balance the logics, such as being a member of the owning family but also an educated journalist. Moreover, these logics not only have a personal dimension but are also relevant for the organisation in a family-firm context. Trained family members become central as the only ones who can access all logics. Anyone can become a manager and relate to management structures. Similarly, anyone can become a journalist by education and/or experience. However, not just anyone can become a family member. This explains the important position of family members, especially hybrid ownermanagers, in balancing different logics and choosing to balance family logic with other logics. Similar explanations have been presented in healthcare research in which it has proved very important to balance physicians' approaches to competing logics, as physicians can become managers, but managers cannot easily become physicians (e.g. Andersson, 2015). Similarly, another question looks at the field or industry levels.

Finally, our results also contribute to the diversity or heterogeneity of family firms (Reay et al., 2015) because there appears to be a clear difference in how owning families approach logics, which means that there is no single prescribed way of handling multiple logics. We agree with Reay et al. (2015) that future research should look at generational differences. Different logics may dominate at different points of the organisational life. However, the role of non-family members, such as CEOs or other top managers, can equally influence the direction and balance of multiple logics.

There are also important practical contributions for family businesses from this research. Currently, there is a strong stream of research that emphasises that family businesses must professionalise management. The present study nuances this line of reasoning. Management and professional logics that are relevant to a particular industry can contribute to a 
successful family business, but these should not replace family logic. Making management logic superior to family logic could be devastating for family firms. However, adding/ allowing different logics increases complexity; therefore, balancing different logics should be a key competence in running family businesses. With regard to the next generation of family owners, socialisation and education become even more central, as they influence how challenging multiple logics are handled.

\subsection{Limitations and future research}

This study draws on two family-owned newspaper companies. However, more research is required to investigate other professions and industries in family firms, such as the medical or legal profession (Albert and Adams, 2002; Freidson, 2001; Scott, 2008) or even the arts (Litz, 2010), as family firms play a significant role there as well. The importance of family firms varies across industries (Andersson et al., 2018) and can be more prominent in certain industries (Carcano et al., 2011; Ljungkvist and Boers, 2017); this is a potential topic for future research. Furthermore, the recent COVID-19 pandemic has affected many family firms (Boers and Henschel, 2021); it can be assumed that social distancing has led to more meetings being held virtually rather than in person, which could further decrease accessibility to different arenas.

Future research could investigate further and other combinations of institutional logics, as well as how other actors such as non-family members handle these logics, in non-family firms or public organisations.

\section{Notes}

1. The name of the company and those of interviewees were anonymised.

2. The name of the company and those of interviewees were anonymised.

\section{References}

Abbott, A.D. (1988), The System of Professions: An Essay on the Division of Expert Labor, University of Chicago Press, Chicago.

Achtenhagen, L. and Raviola, E. (2009), "Balancing tensions during convergence: duality management in a newspaper company", International Journal on Media Management, Vol. 11 No. 1, pp. 32-41.

Albert, S. and Adams, E. (2002), "The hybrid identity of law firms", in Moingeon, B. and Soenen, G. (Eds), Corporate and Organizational Identities, Routledge, London, New York, pp. 35-50.

Albert, S., Godfrey, P.C. and Whetten, D.A. (1999), Hybrid Identity Organisations, Brigham Young University Marriott School of Management, Provo, Utah.

Alvehus, J. and Andersson, T. (2018), "A new professional landscape: entangled institutional logics in two Swedish welfare professions", Nordic Journal of Working Life Studies, Vol. 8 No. 3, pp. 91-109.

Andersson, T. (2015), "The medical leadership challenge in healthcare is an identity challenge", Leadership in Health Services, Vol. 28 No. 2, pp. 83-99.

Andersson, T. and Gadolin, C. (2020), "Understanding institutional work through social interaction in highly institutionalized settings: lessons from public healthcare organizations", Scandinavian Journal of Management, Vol. 36 No. 2, p. 101107.

Andersson, T. and Liff, R. (2018), "Co-optation as a response to competing institutional logics: professionals and managers in healthcare", Journal of Professions and Organization, Vol. 5 No. 2, pp. 71-87.

Andersson, F.W., Johansson, D., Karlsson, J., Lodefalk, M. and Poldahl, A. (2018), “The characteristics of family firms: exploiting information on ownership, kinship, and governance using total population data", Small Business Economics, Vol. 51, pp. 1-18. 
Aparicio, G., Basco, R., Iturralde, T. and Maseda, A. (2017), "An exploratory study of firm goals in the context of family firms: an institutional logics perspective", Journal of Family Business Strategy, Vol. 8 No. 3, pp. 157-169.

Arregle, J.-L., Hitt, M.A., Sirmon, D.G. and Very, P. (2007), "The development of organizational social capital: attributes of family firms", Journal of Management Studies, Vol. 44 No. 1, pp. 73-95.

Astrachan, J.H., Klein, S.B. and Smyrnios, K.X. (2002), "The F-PEC scale of family influence: a proposal for solving the family business definition problem", Family Business Review, Vol. 15 No. 1, pp. 45-58.

Basco, R. (2019), "What kind of firm do you owner-manage? An institutional logics perspective of individuals' reasons for becoming an entrepreneur", Journal of Family Business Management, Vol. 9 No. 3, pp. 297-318.

Besharov, M.L. and Smith, W.K. (2014), "Multiple institutional logics in organizations: explaining their varied nature and implications", Academy of Management Review, Vol. 39 No. 3, pp. 364-381.

Bévort, F. and Suddaby, R. (2016), "Scripting professional identities: how individuals make sense of contradictory institutional logics", Journal of Professions and Organization, Vol. 3 No. 1, pp. 17-38.

Bjursell, C. and Bäckvall, L. (2011), "Family business women in media discourse: the business role and the mother role", Journal of Family Business Management, Vol. 1 No. 2, pp. 154-173.

Blomgren, M. and Waks, C. (2015), "Coping with contradictions: hybrid professionals managing institutional complexity", Journal of Professions and Organization, Vol. 2 No. 1, pp. 78-102.

Boers, B. and Henschel, T. (2021), "The role of entrepreneurial orientation in crisis management: evidence from family firms in enterprising communities", Journal of Enterprising Communities: People and Places in the Global Economy, ahead-of-print, doi: 10.1108/JEC-12-2020-0210.

Boers, B. and Nordqvist, M. (2012), "Understanding hybrid-identity organizations: the case of publicly listed family businesses", in Carsrud, A. and Brännback, M. (Eds), Understanding Family Businesses, Springer, New York, pp. 251-269.

Boers, B. and Nordqvist, M. (2020), "Family businesses as hybrid organisations", in Billis, D. and Rochester, C. (Eds), Handbook on Hybrid Organisations, Edward Elgar Publishing, Cheltenham, pp. 507-521.

Boers, B., Ljungkvist, T., Brunninge, O. and Nordqvist, M. (2017), "Going private: a socioemotional wealth perspective on why family controlled companies decide to leave the stock-exchange", Journal of Family Business Strategy, Vol. 8 No. 2, pp. 74-86.

Brundin, E. and Melin, L. (2012), "Managerial practices in family owned firms: strategizing actors, their arenas and their emotions", in Tengblad, S. (Ed.), The Work of Managers, Oxford University Press, Oxford, pp. 281-298.

Brundin, E., Samuelsson, E.F. and Melin, L. (2014), "Family ownership logic: framing the core characteristics of family businesses", Journal of Management and Organization, Vol. 20 No. 1, pp. 6-37.

Carcano, L., Corbetta, G. and Minichilli, A. (2011), "Why luxury firms are often family firms? Family identity, symbolic capital and value creation in luxury-related industries", Universia Business Review, Vol. 32, pp. 40-53.

Chandler, A.D. (1990), Strategy and Structure: Chapters in the History of the Industrial Enterprise, MIT Press, Cambrigde, MA.

Chua, J.H., Chrisman, J.J. and Sharma, P. (1999), "Defining the family business by behavior", Entrepreneurship: Theory, and Practice, Vol. 23 No. 4, pp. 19-39.

Currie, G., Burgess, N. and Hayton, J.C. (2015), "HR practices and knowledge brokering by hybrid middle managers in hospital settings: the influence of professional hierarchy", Human Resource Management, Vol. 54 No. 5, pp. 793-812.

Currie, G. and Spyridonidis, D. (2016), "Interpretation of multiple institutional logics on the ground: actors' position, their agency and situational constraints in professionalized contexts", Organization Studies, Vol. 37 No. 1, pp. 77-97. 
De Massis, A. and Kotlar, J. (2014), "The case study method in family business research: guidelines for qualitative scholarship”, Journal of Family Business Strategy, Vol. 5 No. 1, pp. 15-29.

Djankov, S., McLiesh, C., Nenova, T. and Shleifer, A. (2003), "Who owns the media?", Journal of Law and Economics, Vol. 46 No. 2, pp. 341-382.

Djerf-Pierre, M. and Weibull, L. (2011), "From idealist-entrepreneur to corporate executive: provincial newspaper editors' and publishers' ways-of-thinking from the mid-1800s to the present", Journalism Studies, Vol. 12 No. 3, pp. 294-310.

Dybski, W., Hanel, K., Kringe, A., Peun, K. and Weiss, R. (2010), “Ideologie vor Eigennutz?”, Publizistik, Vol. 55 No. 2, pp. 173-192.

Dyer, W.G. (1989), "Integrating professional management into a family owned business", Family Business Review, Vol. 2 No. 3, pp. 221-235.

Eisenhardt, K.M. (1989), "Building theories from case study research", Academy of Management Review, Vol. 14 No. 4, pp. 532-550.

Eisenhardt, K.M. and Graebner, M.E. (2007), "Theory building from cases: opportunities and challenges", Academy of Management Journal, Vol. 50 No. 1, pp. 25-32.

Everitt, J.G. (2012), "Teacher careers and inhabited institutions: sense-making and arsenals of teaching practice in educational institutions", Symbolic Interaction, Vol. 35 No. 2, pp. 203-220, doi: 10. 1002/symb.16.

Fletcher, D., Massis, A.D. and Nordqvist, M. (2016), "Qualitative research practices and family business scholarship: a review and future research agenda", Journal of Family Business Strategy, Vol. 7 No. 1, pp. 8-25.

Foreman, P. and Whetten, D.A. (2002), "Members' identification with multiple-identity organisations", Organisation Science, Vol. 13 No. 6, pp. 618-635.

Freidson, E. (2001), Professionalism, the Third Logic: On the Practice of Knowledge, University of Chicago Press, Chicago.

Gadolin, C. (2018), "Professional employees' strategic employment of the managerial logic in healthcare", Qualitative Research in Management and Organizations: An International Journal, Vol. 13 No. 2, pp. 126-143.

Gadolin, C. and Andersson, T. (2017), "Healthcare quality improvement work: a professional employee perspective", International Journal of Health Care Quality Assurance, Vol. 30 No. 5, pp. 410-423.

Gersick, K.E., Davis, J.A., Hampton, M.M. and Lansberg, I. (1997), Generation to Generation: Life Cycles of the Family Business, Harvard Business School Press, Cambridge, MA.

Gómez-Mejia, L.R., Cruz, C., Berrone, P. and De Castro, J. (2011), "The bind that ties: socioemotional wealth preservation in family firms", Academy of Management Annals, Vol. 5 No. 1, pp. 653-707.

Goodrick, E. and Reay, T. (2011), "Constellations of institutional logics: changes in the professional work of pharmacists", Work and Occupations, Vol. 38 No. 3, pp. 372-416.

Greenwood, R., Diaz, A.M., Li, S.X. and Lorente, J.C. (2010), "The multiplicity of institutional logics and the heterogeneity of organizational responses", Organization Science, Vol. 21 No. 2, pp. 521-542.

Greenwood, R., Raynard, M., Kodeih, F., Micelotta, E. and Lounsbury, M. (2011), "Institutional complexity and organizational responses", Academy of Management Annals, Vol. 5 No. 1, pp. 317-371.

Hall, A. and Nordqvist, M. (2008), "Professional management in family businesses: toward an extended understanding", Family Business Review, Vol. 21 No. 1, pp. 51-69.

Hallett, T. (2010), "The myth incarnate: recoupling processes, turmoil, and inhabited institutions in an urban elementary school", American Sociological Review, Vol. 75 No. 1, pp. 52-74.

Hallin, D.C. and Mancini, P. (2004), Comparing Media Systems, Cambridge University Press, Cambridge.

Ingram, A.E., Lewis, M.W., Barton, S. and Gartner, W.B. (2016), "Paradoxes and innovation in family firms: the role of paradoxical thinking", Entrepreneurship Theory and Practice, Vol. 40 No. 1, pp. 161-176. 
Jager, U.P. and Schroer, A. (2014), "Integrated organizational identity: a definition of hybrid organizations and a research agenda", VOLUNTAS: International Journal of Voluntary and Nonprofit Organizations, Vol. 25 No. 5, pp. 1281-1306.

James, A., Hadjielias, E., Guerrero, M., Discua Cruz, A. and Basco, R. (2021), "Entrepreneurial families in business across generations, contexts and cultures", Journal of Family Business Management, Vol. 11 No. 4, pp. 355-367.

Jaskiewicz, P., Heinrichs, K., Rau, S.B. and Reay, T. (2016), "To be or not to be: how family firms manage family and commercial logics in succession", Entrepreneurship Theory and Practice, Vol. 40 No. 4, pp. 781-813.

Konopaski, M., Jack, S. and Hamilton, E. (2015), "How family business members learn about continuity", Academy of Management Learning, and Education, Vol. 14 No. 3, pp. 347-364.

Leaptrott, J. (2005), "An institutional theory view of the family business", Family Business Review, Vol. 18 No. 3, pp. 215-228.

Leonard-Barton, D. (1990), "A dual methodology for case studies: synergistic use of a longitudinal single site with replicated multiple sites", Organization Science, Vol. 1 No. 3, pp. 248-266.

Liff, R. and Andersson, T. (2011), "Integrating or disintegrating effects of customised care - the role of professions beyond NPM", Journal of Health Organization and Management, Vol. 25 No. 6, pp. 658-676.

Litz, R.A. (2010), "Jamming across the generations: creative intergenerational collaboration in the Marsalis family", Journal of Family Business Strategy, Vol. 1 No. 4, pp. 185-199.

Ljungkvist, T. and Boers, B. (2017), "Another hybrid? Family businesses as venture capitalists", Journal of Family Business Management, Vol. 7 No. 3, pp. 329-350.

Martin, G., Currie, G., Weaver, S., Finn, R. and McDonald, R. (2017), "Institutional complexity and individual responses: delineating the boundaries of partial autonomy", Organization Studies, Vol. 38 No. 1, pp. 103-127.

Matias, C. and Franco, M. (2021), "The role of the family council and protocol in planning the succession process in family firms", Journal of Family Business Management, Vol. 11 No. 4, pp. $440-461$.

McPherson, C.M. and Sauder, M. (2013), "Logics in action: managing institutional complexity in a drug court", Administrative Science Quarterly, Vol. 58 No. 2, pp. 165-196.

Melin, L. and Nordqvist, M. (2007), "The reflexive dynamics of institutionalization: the case of the family business", Strategic Organization, Vol. 5 No. 3, pp. 321-333.

Miller, D., Le Breton-Miller, I. and Lester, R.H. (2011), "Family and lone founder ownership and strategic behaviour: social context, identity, and institutional logics", Journal of Management Studies, Vol. 48 No. 1, pp. 1-25.

Nordqvist, M. (2012), "Understanding strategy processes in family firms: exploring the roles of actors and arenas", International Small Business Journal, Vol. 30 No. 1, pp. 24-40.

Nordqvist, M. (2016), "Socio-symbolic ownership: extending the socio-emotional wealth perspective", Management Research: Journal of the Iberoamerican Academy of Management, Vol. 14 No. 3, pp. 244-257.

Nordqvist, M. and Melin, L. (2002), "The dynamics of family firms: an institutional perspective on corporate governance and strategic change", in Fletcher, D.E. (Ed.), Understanding the Small Family Business, Routledge, London, pp. 94-110.

Nordqvist, M., Hall, A. and Melin, L. (2009), "Qualitative research on family businesses: the relevance and usefulness of the interpretive approach”, Journal of Management and Organization, Vol. 15 No. 3, pp. 294-308.

Pache, A.C. and Santos, F. (2013), "Inside the hybrid organization: selective coupling as a response to competing institutional logics", Academy of Management Journal, Vol. 56 No. 4, pp. 972-1001. 
Parada, M.J., Nordqvist, M. and Gimeno, A. (2010), "Institutionalizing the family business: the role of professional associations in fostering a change of values", Family Business Review, Vol. 23 No. 4, pp. 355-372.

Parada, M.J., Gimeno, A., Samara, G. and Saris, W. (2020), "The adoption of governance mechanisms in family businesses: an institutional lens", Journal of Family Business Management, ahead of print, doi: 10.1108/JFBM-07-2019-0054.

Perkmann, M., McKelvey, M. and Phillips, N. (2019), "Protecting scientists from gordon Gekko: how organizations use hybrid spaces to engage with multiple institutional logics", Organization Science, Vol. 30 No. 2, pp. 298-318.

Picard, R.G. (2004), "A typology of risk in family media enterprises”, Journal of Media Business Studies, Vol. 1 No. 1, pp. 71-83.

Picard, R.G. and van Weezel, A. (2008), "Capital and control: consequences of different forms of newspaper ownership", International Journal on Media Management, Vol. 10 No. 1, pp. 22-31.

Polat, G. (2021), "Advancing the multidimensional approach to family business professionalization", Journal of Family Business Management, Vol. 11 No. 4, pp. 555-571.

Raviola, E. (2012), "Exploring organizational framings", Information, Communication and Society, Vol. 15 No. 6, pp. 932-958.

Raviola, E. and Norbäck, M. (2013), "Bringing technology and meaning into institutional work: making news at an Italian business newspaper", Organization Studies, Vol. 34 No. 8, pp. 1171-1194.

Reay, T. (2009), "Family business meta identity, institutional pressures, and ability to respond to entrepreneurial opportunities", Entrepreneurship Theory and Practice, Vol. 33 No. 6, pp. 1265-1270.

Reay, T. and Hinings, C.R.B. (2009), "Managing the rivalry of competing institutional logics", Organization Studies, Vol. 30 No. 6, pp. 629-652.

Reay, T. and Jones, C. (2016), "Qualitatively capturing institutional logics", Strategic Organization, Vol. 14 No. 4, pp. 441-454.

Reay, T., Jaskiewicz, P. and Hinings, C.R. (2015), "How family, business, and community logics shape family firm behavior and "rules of the game" in an organizational field"', Family Business Review, Vol. 28 No. 4, pp. 292-311.

Reay, T., Goodrick, E., Waldorff, S.B. and Casebeer, A. (2017), "Getting leopards to change their spots: co-creating a new professional role identity", Academy of Management Journal, Vol. 60 No. 3, pp. 1043-1070.

Salvato, C., Chirico, F. and Sharma, P. (2010), "A farewell to the business: championing exit and continuity in entrepreneurial family firms", Entrepreneurship and Regional Development, Vol. 22 No. 3, pp. 321-348.

Scott, W.R. (2008), "Lords of the dance: professionals as institutional agents", Organization Studies, Vol. 29 No. 2, pp. 219-238.

Sharma, P., Salvato, C. and Reay, T. (2014), "Temporal dimensions of family enterprise research", Family Business Review, Vol. 27 No. 1, pp. 10-19.

Siggelkow, N. (2007), "Persuasion with case studies", Academy of Management Journal, Vol. 50 No. 1, pp. 20-24.

Soleimanof, S., Rutherford, M.W. and Webb, J.W. (2018), "The intersection of family firms and institutional contexts: a review and agenda for future research", Family Business Review, Vol. 31 No. 1, pp. 32-53.

Songini, L. (2006), "The professionalization of family firm: theory and practice", in Poutziouris, P., Smyrnios, K.X. and Klein, S.B. (Eds), Handbook of Research on Family Business, Edward Elgar Publishing, Cheltenham, pp. 269-297.

Songini, L. and Vola, P. (2014), "The role of managerialization and professionalization in family business succession: evidences from Italian enterprises”, in Gnan, L., Lundberg, H., Songini, L. 
and Pellegrini, M. (Eds), Advancing European Entrepreneurship Research, Information Age Publishing, Charlotte, NC, pp. 169-196.

Songini, L. and Vola, P. (2015), "The role of professionalization and managerialization in family business succession”, Management Control, Vol. 1, pp. 9-43.

Steinerowska-Streb, I. and Wziątek-Staśko, A. (2020), "Innovations in family firms: a study of ownermanagers' knowledge development", Journal of Family Business Management, Vol. 10 No. 3, pp. 247-264.

Stewart, A. and Hitt, M.A. (2012), "Why can't a family business be more like a nonfamily business? Modes of professionalization in family firms", Family Business Review, Vol. 25 No. 1, pp. 58-86.

Sundin, S. (2009), "Media ownership in the Nordic countries. Current trends", in Harrie, E. (Ed.), The Nordic Media Market 2009. Media Companies and Business Activities, Nordicom, Gothenborg, pp. 7-12.

Tagiuri, R. and Davis, J. (1996), "Bivalent attributes of the family firm”, Family Business Review, Vol. 9 No. 2, pp. 199-208.

Thornton, P.H. (2004), Markets from Culture: Institutional Logics and Organizational Decisions in Higher Education Publishing, Stanford University Press, Stanford, CA.

Thornton, P.H. and Ocasio, W. (2008), "Institutional logics", in Greenwood, R., Oliver, C., Suddaby, R. and Sahlin-Andersson, K. (Eds), The Sage Handbook of Organizational Institutionalism, Sage Publications, London, pp. 99-129.

Thornton, P.H., Ocasio, W. and Lounsbury, M. (2012), The Institutional Logics Perspective: A New Approach to Culture, Structure and Process, Oxford University Press, Oxford.

Wright, M., Chrisman, J.J., Chua, J.H. and Steier, L.P. (2014), "Family enterprise and context", Entrepreneurship Theory and Practice, Vol. 38 No. 6, pp. 1247-1260.

Zaman, S., Arshad, M., Sultana, N. and Saleem, S. (2021), "The effect of family business exposure on individuals' entrepreneurial intentions: an institutional theory perspective", Journal of Family Business Management, Vol. 11 No. 4, pp. 368-385.

Zellweger, T.M., Nason, R.S., Nordqvist, M. and Brush, C.G. (2013), "Why do family firms trive for nonfinancial performance? An organizational identity perspective", Entrepreneurship Theory and Practice, Vol. 37 No. 2, pp. 229-248.

\section{Further reading}

Boter, H. and Holmquist, C. (1996), "Industry characteristics and internationalization processes in small firms", Journal of Business Venturing, Vol. 11 No. 6, pp. 471-487.

Faccio, M. and Lang, L.H. (2002), "The ultimate ownership of Western European corporations", Journal of Financial Economics, Vol. 65 No. 3, pp. 365-395.

Gioia, D.A. and Pitre, E. (1990), "Multiparadigm perspectives on theory building", Academy of Management Review, Vol. 15 No. 4, pp. 584-602.

Gómez-Mejía, L.R., Haynes, K.T., Núñez-Nickel, M., Jacobson, K. and Moyano-Fuentes, J. (2007), "Socioemotional wealth and business risks in family-controlled firms: evidence from Spanish olive oil mills", Administrative Science Quarterly, Vol. 52 No. 1, pp. 106-137.

Levinson, H. (1971), "Conflicts that plague family business”, Harvard Business Review, Vol. 49 No. 2, pp. $90-98$.

Micelotta, E.R. and Fairclough, S. (2013), "Beyond the family firm: reasserting the influence of the family institutional logic across organizations", in Lounsbury, M. and Boxenbaum, E. (Eds), Institutional Logics in Action, Part B, Emerald Group Publishing, Bingley, pp. 63-98.

Pettigrew, A.M. (1987), "Context and action in the transformation of the firm”, Journal of Management Studies, Vol. 24 No. 6, pp. 649-670. 
Prasad, A. and Prasad, P. (2002), "The coming of age of interpretive organizational research", Organizational Research Methods, Vol. 5 No. 1, pp. 4-11.

Whetten, D.A. (2009), "An examination of the interface between context and theory applied to the study of Chinese organizations", Management and Organization Review, Vol. 5 No. 1, pp. 29-55.

Zellweger, T.M., Eddleston, K.A. and Kellermanns, F.W. (2010), "Exploring the concept of familiness: introducing family firm identity”, Journal of Family Business Strategy, Vol. 1 No. 1, pp. 54-63.

Family

members as

hybrid owner-

managers

\begin{abstract}
About the authors
Börje Boers is associate professor at the School of Business, University of Skövde, Sweden, where he is part of the research group of Strategic Entrepreneurship. He has published in journals such as Journal of Family Business Strategy, Management Revue, International Journal of Entrepreneurial Behavior and Research, Journal of Enterprising Communities and Journal of Family Business Management. Börje Boers is the corresponding author and can be contacted at: borje.boers@his.se

Thomas Andersson is professor at the University of Skövde, Sweden, where he is leading the research group Followership and Organizational resilience. He has published in journals such as Public Management Review, Journal of Professions and Organization, Scandinavian Journal of Management, Personnel Review and Qualitative Research in Accounting and Management.
\end{abstract}

For instructions on how to order reprints of this article, please visit our website: 